\title{
PATTERNS OF HETEROGENEITY WITHIN PHREATIC KARST AQUIFERS OF THE GREAT VALLEY, VIRGINIA AND WEST VIRGINIA: EVIDENCE FROM TIME SERIES HYDROLOGIC MONITORING, GROUNDWATER CHEMISTRY, AND STYGOBITE SITE OCCUPANCY
}

\author{
Wil Orndorff \\ Natural Heritage Program, Virginia Department of Conservation and Recreation, 8 Radford Street, Suite 102A, \\ Christiansburg,VA 24073,Wil.Orndorff@dcr.virginia.gov
}

Daniel H. Doctor

U.S. Geological Survey, Eastern Geology and Paleoclimate Science Center, 12201 Sunrise Valley Drive, MS 926A, Reston,VA20192,dhdoctor@usgs.gov

Tom Malabad

Natural Heritage Program, Virginia Department of Conservation and Recreation, 8 Radford Street, Suite 102A, Christiansburg,VA 24073, Tom.Malabad@dcr.virginia.gov

Katarina Kosič Ficco

Natural Heritage Program, Virginia Department of Conservation and Recreation, 8 Radford Street, Suite 102A, Christiansburg,VA 24073, Katarina.Kosic@dcr.virginia.gov

Zenah Orndorff

Crop and Soil Environmental Sciences, 330 Smyth Hall, Virginia Tech, Blacksburg,VA 24061, zenah@vt.edu

\section{Andrea Futrell}

Virginia Speleological Survey, 456 Thistle Lane, ChristiansburgVA 24073, karstmap@hotmail.com

\begin{abstract}
Phreatic karst waters in the Central Appalachian Great Valley are the subject of an ongoing habitat monitoring project across the geographic range of the federally threatened Madison Cave Isopod (MCI, Antrolana lira), a stygobitic crustacean previously documented at each monitoring site. Eight caves and five wells were monitored, via instrumentation, hourly from June 2016 thru October 2017 for water level (WL), temperature (T), and specific conductivity (Cs.) Sites were visited quarterly to download data, collect water samples, and deploy baited traps to assess occupancy by stygobitic fauna. Samples were analyzed for major ions, inorganic carbon, and stable water isotopes. Precipitation data from National Climate Data Center stations were used to evaluate response to precipitation events. There is significant variation between sites in water chemistry, in baseline WL, Cs, and T values, and in the response of these parameters to precipitation. Median temperatures varied from 11.6 to $13.8^{\circ} \mathrm{C}$, with ranges within sites of 0.7 to $15.5^{\circ} \mathrm{C}$. Median Cs values varied from 442 to $726 \mathrm{uS} / \mathrm{cm}$ at $25^{\circ} \mathrm{C}$, with ranges within sites of 16 to $573 \mathrm{uS} / \mathrm{cm}$. Ranges of WL within sites varied from 0.9 to
\end{abstract}

9.6 m. Ten sites exhibited rapid WL increases following precipitation, accompanied by spikes and/or dips in Cs. Six of these sites exhibited significant $T$ changes. Sites with negative Cs response typically exhibited $\mathrm{T}$ changes reflecting precipitation temperature, with several exhibiting a compound response to larger events. Samples analyzed as calcium-magnesium-bicarbonate type waters, with $\mathrm{Ca}: \mathrm{Mg}$ ratios from 9 to $5.5: 1$ and $\mathrm{Ca}+\mathrm{Mg}$ values from 1.8 to $4.1 \mathrm{mmol} / \mathrm{l}$. Geochemical parameters grouped more by site than by season. Chloride, nitrate, sulfate and sodium levels at some sites suggest significant land use influence from agricultural and stormwater management practices. Average $\delta^{2} \mathrm{H}$ and $\delta^{18} \mathrm{O}$ compositions suggest winter-dominated (Nov-April) recharge. Over the course of the study, site occupancy of these known MCI sites ranged from 0 to $100 \%$, both for MCI and other stygobitic invertebrates. Occupancy rates appeared unrelated to geochemical or hydrodynamic patterns. Data are consistent with a complex, compartmentalized phreatic aquifer, reflecting the folded, faulted, and fractured bedrock structure. Water levels determine inter-compartment connectivity, facilitating episodic migration of stygobitic species. 
Characterization of such a system to support groundwater and habitat management decisions would require a much higher spatial density of monitoring stations than presently exists in the Great Valley.

\section{Introduction}

The Madison Cave isopod (Antrolana lira Bowman 1964) is a freshwater, stygobitic cirolanid isopod of marine lineage. The only species in the genus Antrolana, it is known exclusively from phreatic groundwater in the karst aquifer developed in the Cambro-Ordovician aged carbonate rocks of the Great Valley of Virginia and West Virginia (Bowman, 1964; Holsinger et al., 1994; Hutchins et al., 2010.) The Madison Cave isopod is documented from 20 survey sites (12 caves, 8 wells) representing 12 distinct occurrences (Holsinger et al., 2013; Holsinger et al., 1994; Fong, 1996; Orndorff and Hobson, 2007; Hutchins and Orndorff, 2009; Orndorff and Hobson, 2010.) A. lira was listed as threatened over its entire range under the United States Endangered Species Act in 1982 (Fong, 1996). Based on analysis of CO1 mitochrondrial DNA from a subset of sites within its range, Hutchins et al. (2010) separated A. lira into three distinct evolutionary lineages: a southern clade from the type locality at Madison Saltpetre Cave, a western clade just north of Harrisonburg (VA) (3-D Maze, Linville Quarry caves), and a northern clade from sites along the main stem of the Shenandoah River. Hutchins et al. (2010) concluded that the approximate 9.5 to $11.3 \%$ divergence between any two of these clades reflected long term genetic isolation on the order of millions of years, and recognized that DNA analyses of specimens from other sites may identify additional genetic clades. Holsinger et al. (1994) hypothesized that colonization of the Great Valley karst by $A$. lira may have occurred as early as the Cretaceous period.

Prior investigations of the Madison Cave isopod and its habitat have addressed distribution (Fong, 1996; Orndorff and Hobson, 2007; Orndorff, 2008; Orndorff and Hobson, 2010), population estimates based on mark-recapture methods (Fong, 2007; Orndorff, 2012, 2014a, 2014b; Hutchins and Orndorff, 2009), site occupancy and sampling methodology (Hutchins and Orndorff, 2009), molecular genetics (Hutchins et al., 2010,) natural history (Holsinger et al., 1994; Hutchins et al., 2010), population ecology (Collins and Holsinger, 1981; Hutchins and Orndorff, 2009), and habitat characterization and monitoring (Printz, 1999; Orndorff, 2014a, 2014b). Orndorff (2014a, 2014b) showed that hydrological and geochemical characteristics varied significantly between three sampling locations, both in terms of base level values and in responsiveness to precipitation events, even between monitoring locations in close proximity.

This study addresses physical hydrology, geochemistry, and species site occupancy at 13 of the known confirmed survey sites (Figure 1. Study area - site abbreviations listed in Table 1. Karst bedrock distribution from Weary and Doctor (2014).) for A. lira, including eight caves and five wells, in an attempt to better define the range of hydrological and geochemical parameters that characterize its habitat and affect its presence at a specific site. Table 1. Monitoring sites of this study. Locations shown in Figure 1. lists the monitoring sites for this study.

\section{Materials and Methods}

Time series data were collected using automatic data loggers deployed at each site to record specific conductivity, water levels, and temperature at hourly intervals over the course of the study. Instruments in caves were deployed in vertically oriented or steeply sloping stilling well enclosures comprised of 1.5 inch PVC pipe perforated with $1 / 8$ " holes ( 4 per inch), open on the bottom to discourage sediment buildup, and capped on the top to prevent entry of material into the well from above the water level. Instruments were deployed freehanging in wells, and were secured with independent

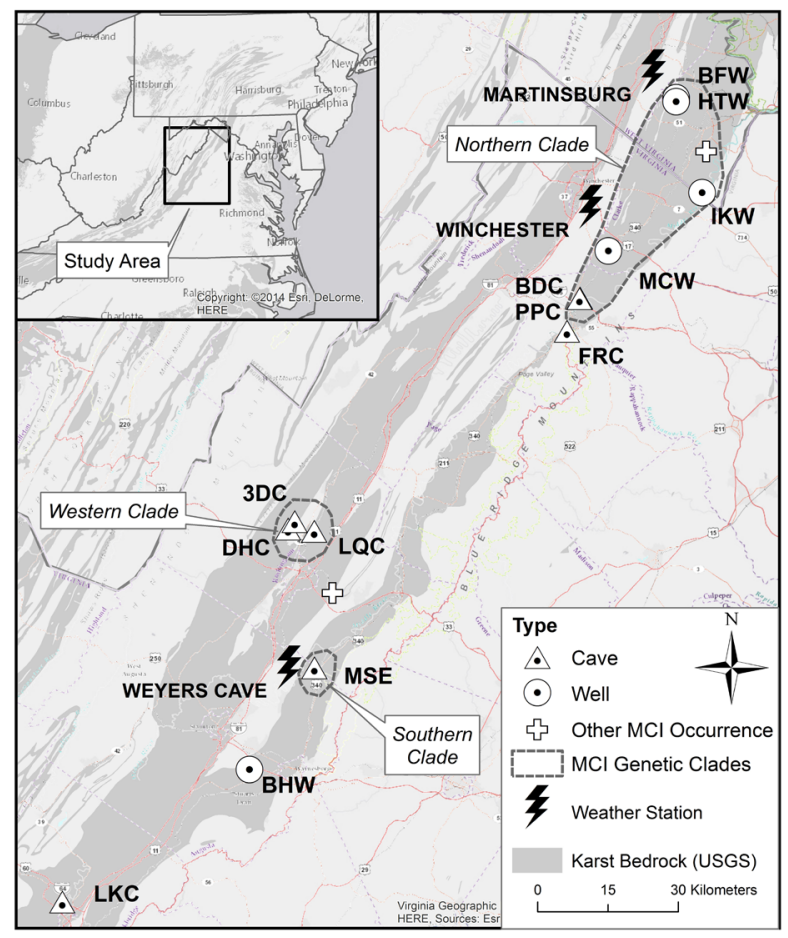

Figure 1. Study area - site abbreviations listed in Table 1. Karst bedrock distribution from Weary and Doctor (2014). 


\begin{tabular}{|l|c|c|}
\hline Site & Abbr. & Type \\
\hline 3-D Maze Cave & 3DC & Cave \\
\hline Brother Daves Cave & BDC & Cave \\
\hline Devils Hole & DHC & Cave \\
\hline Front Royal Caverns & FRC & Cave \\
\hline Lime Kiln Cave & LKC & Cave \\
\hline Linville Quarry Cave & LQC & Cave \\
\hline $\begin{array}{l}\text { Madison Saltpetre Cave (East } \\
\text { Lake) }\end{array}$ & MSE & Cave \\
\hline Power Plant Pit & PPC & Cave \\
\hline Ballfield Well & BFW & Well (drilled) \\
\hline Blue Hole Well & BHW & Well/cave \\
\hline Howard Tabb Well & HTW & Well (dug) \\
\hline Irvin King Well & IKW & Well (drilled) \\
\hline Meade Church Well & MCW & Well (dug) \\
\hline
\end{tabular}

Table 1. Monitoring sites of this study. Locations shown in Figure 1.

and redundant nylon cord and/or plastic coated steel wire. Depth was recorded using Onset ${ }^{\circledR} \mathrm{HOBO}{ }^{\circledR}$ U20L-01 Water Level Data Loggers specified for use up to $10 \mathrm{~m}$ depth and accurate to $0.5 \mathrm{~cm}$. These loggers also record temperatures to within $0.44^{\circ} \mathrm{C}$. These loggers were placed at arbitrary depths below the water surface, at elevations below which it appeared the water table rarely (if ever) recedes. U20 Water Level Data Loggers were also deployed above maximum water level to $\log$ barometric pressure facilitating calculation of sensor depth using Onset ${ }^{\circledR}$ Hoboware ${ }^{\circledR}$ software. Specific conductivity was measured using a HOBO Freshwater Conductivity Data Logger - U24-001, factory calibrated for the range of 0 to $1,000 \mu \mathrm{S} / \mathrm{cm}$ accurate to within the greater of $3 \%$ of the reading or $5 \mathrm{uS} / \mathrm{cm}$. Data were corrected using Onset Hoboware software to specific conductivity to eliminate temperature effects $(\sim 2 \%$ per ${ }^{\circ} \mathrm{C}$ ) so that all changes in conductivity could be attributed to changes in ionic composition of the groundwater. Hourly precipitation data were downloaded from National Climate Data Center weather stations proximal to study sites to facilitate analysis of time series data response to precipitation events.

Water samples were collected in December 2016, March 2017, and July 2017, and were filtered to 0.2 microns to remove sediment and microorganisms. Major cation samples were acidified and analyzed using an inductively-coupled mass spectrometer (ICP-MS), and anion samples were analyzed by ion chromatography (IC) at Virginia Tech. Samples for total inorganic carbon analysis were collected in gas-tight glass vials without headspace, and analyzed by a total carbon analyzer interfaced with an isotope ratio mass spectrometer (IRMS) at the U.S. Geological Survey (USGS) in
Reston according to methods described in Révész and Doctor (2014). Samples for oxygen and hydrogen stable isotope analyses were analyzed at the USGS Reston Stable Isotope Laboratory. All samples were refrigerated until analysis. Approximately $10 \%$ of the samples were collected in duplicate for cross-comparison among analytical results.

Site occupancy was assessed using a combination of stygobite traps (caves and wells) and visual observation (caves). Traps baited with raw shrimp or salmon eggs (Hutchins and Orndorff, 2009) were deployed quarterly for approximately 24 hours. Specimens were counted and identified to the extent possible then returned to habitat, except in cases where taxonomic uncertainty existed or additional specimens were required for ongoing genetic investigations pursuant to Hutchins et al. (2010). Collections were performed under permits issued by Virginia DGIF and West Virginia DNR.

\section{Results}

Time series data statistics are summarized in Table 2 and expressed graphically in Figure 2. A complete set of time series data are available upon request from the first author.

Water level values are reported as meters above minimum recorded levels. Three sites in close proximity - 3-D Maze, Linville Quarry, and Devils Hole - spent a significant portion of the study period dry when water levels receded below the instruments, so relative water levels and ranges are underestimated for these sites. Among the remaining sites, the highest range of water levels was observed at Power Plant Pit at $9.55 \mathrm{~m}$, and the lowest at Madison Saltpetre Cave (East Lake) at $1.06 \mathrm{~m}$. Highest median water level was at Meade Church Well $(1.80 \mathrm{~m})$ and the lowest at Brother Daves Cave $(0.03 \mathrm{~m})$.

Temperatures reported are those collected by submerged pressure transducers. The highest median temperatures observed were at Power Plant Pit $\left(13.6^{\circ} \mathrm{C}\right)$ and Meade Church well $\left(13.9^{\circ} \mathrm{C}\right)$. The lowest median temperatures were at Devils Hole $\left(11.9^{\circ} \mathrm{C}\right)$ and Front Royal Caverns $\left(11.7^{\circ} \mathrm{C}\right)$. The highest $\left(22.5^{\circ} \mathrm{C}\right)$ and lowest temperatures $\left(7.0^{\circ} \mathrm{C}\right)$ observed were at Power Plant Pit, defining a range of $15.5^{\circ} \mathrm{C}$. Madison Saltpetre Cave (East Lake) exhibited the smallest range of temperatures at $0.1^{\circ} \mathrm{C}$.

The highest median specific conductance values reported were from Howard Tabb Well $(794 \mu \mathrm{S} / \mathrm{cm})$, Power Plant Pit $(726 \mu \mathrm{S} / \mathrm{cm})$, and Meade Church Well $(717 \mu \mathrm{S} /$ $\mathrm{cm}$.) Lowest median values were reported for Madison 


\begin{tabular}{|c|c|c|c|c|c|c|c|c|c|c|c|c|}
\hline \multirow{2}{*}{ Site name } & \multirow{2}{*}{ Site Abr. } & \multicolumn{3}{|c|}{ Level (m) } & \multicolumn{4}{|c|}{ Temp $\left({ }^{\circ} \mathrm{C}\right)$} & \multicolumn{4}{|c|}{ Specific Conductance $(\mu \mathrm{S} / \mathrm{cm})$} \\
\hline & & med & $\mathrm{R}$ & $\mathrm{SD}$ & med & $\max$ & $\min$ & SD & med & $\max$ & $\min$ & SD \\
\hline 3-D Maze Cave & $3 \mathrm{DC} 1$ & 0.21 & 3.71 & 0.68 & 12.4 & 13.7 & 11.2 & 0.30 & 702 & 733 & 519 & 19 \\
\hline Brother Daves Cave & $\mathrm{BDC}$ & 0.03 & 5.01 & 0.21 & 12.2 & 13.3 & 12.1 & 0.11 & 607 & 668 & 439 & 18 \\
\hline Devils Hole & $\mathrm{DHC1}$ & 2.15 & 4.79 & 1.4 & 11.9 & 12.0 & 10.2 & 0.54 & 724 & 776 & 556 & 47 \\
\hline Front Royal Caverns & FRC & 0.25 & 7.34 & 1.1 & 11.7 & 12.3 & 10.9 & 0.11 & 693 & 984 & 574 & 69 \\
\hline Lime Kiln Cave & LKC & 0.04 & 4.93 & 0.33 & 13.1 & 15.8 & 11.8 & 0.14 & 450 & 492 & 233 & 14 \\
\hline Linville Quarry Cave & LQC1 & 2.63 & 5.99 & 2.1 & 12.6 & 13.1 & 12.0 & 0.09 & 639 & 680 & 600 & 14 \\
\hline $\begin{array}{l}\text { Madison Saltpetre Cave (East } \\
\text { Lake) }\end{array}$ & MSE & 0.25 & 1.06 & 0.23 & 12.2 & 12.2 & 12.1 & 0.04 & 468 & 477 & 458 & 5 \\
\hline Power Plant Pit & PPC & 0.77 & 9.55 & 1.1 & 13.6 & 22.5 & 7.0 & 0.47 & 726 & 765 & 192 & 54 \\
\hline Ballfield Well & BFW & 0.76 & 1.64 & 0.32 & 12.5 & 13.4 & 11.5 & 0.41 & 660 & 688 & 630 & 11 \\
\hline Blue Hole Well & BHW & 0.96 & 2.81 & 0.62 & 13.0 & 13.1 & 12.2 & 0.10 & 442 & 449 & 439 & 2.6 \\
\hline Howard Tabb Well & HTW2 & 0.61 & 1.64 & 0.40 & \multicolumn{4}{|c|}{ Influenced by well pump } & 794 & 1093 & 101 & 81 \\
\hline Irvin King Well & IKW & 1.39 & 6.43 & 1.41 & 12.5 & 14.3 & 12.4 & 0.02 & 590 & 618 & 137 & 45 \\
\hline Meade Church Well & $\mathrm{MCW}$ & 1.80 & 6.75 & 1.40 & 13.9 & 14.2 & 13.4 & 0.18 & 717 & 825 & 622 & 34 \\
\hline
\end{tabular}

Table 2. Water level and temperature time series statistics. 1-water receded below loggers during significant portion of study period; 2-water level affected by pumping (med=median, max=maximum, min=minimum, $R=$ range, $S D=$ standard deviation). Site abbreviations listed in Table 1 .

Saltpetre Cave (East Lake, $468 \mu \mathrm{S} / \mathrm{cm}$ ), Lime Kiln Cave $(450 \mu \mathrm{S} / \mathrm{cm})$ and Blue Hole Well $(442 \mu \mathrm{S} / \mathrm{cm})$. The highest ranges in specific conductance values were at Howard Tabb Well $(992 \mu \mathrm{S} / \mathrm{cm})$ and Power Plant Pit $(573 \mu \mathrm{S} / \mathrm{cm}$.) The lowest ranges in specific conductance were at Madison Saltpetre Cave $(19 \mu \mathrm{S} / \mathrm{cm})$ and Blue Hole Well $(10 \mu \mathrm{S} / \mathrm{cm})$.

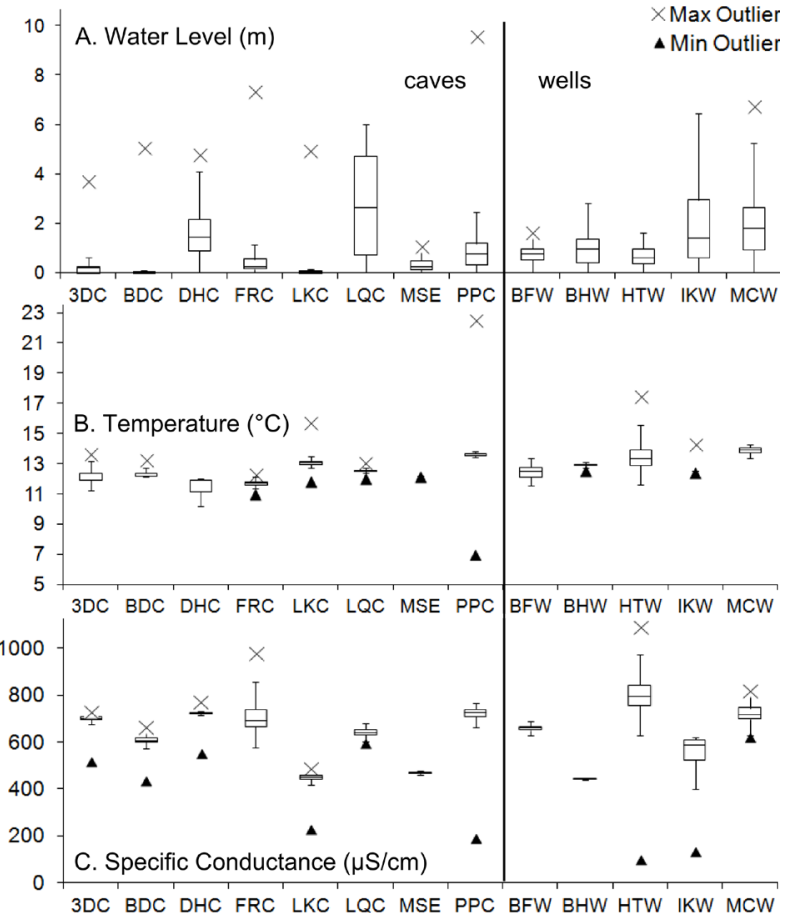

Figure 2. Box plot summaries of time series data (A. Water level, B. Temperature, and C. Specific conductance)
Time series data were plotted over time against precipitation to assess and compare parameter responses to precipitation events. Figure 3 displays the responses of the Northern sites, while Figure 4 shows those of the Southern sites. Howard Tabb Well was excluded from these plots due to strong suspected influence from pumping and well maintenance activities.

Water level was the only parameter responsive to precipitation across all study sites. Power Plant Pit, Front Royal Caverns, and Meade Church Well respond immediately to most precipitation events over $1 / 4$ inch, while the remaining sites respond to larger events typically exceeding $1 / 2$ inch. Ballfield Well level response is irregular. Blue Hole Well and Madison Saltpetre Cave show slow responses to larger precipitation events, with an increase in base level values subsequent to the events. Power Plant Pit, Irvin King Well, and Meade Church Well also show increases in base trends after storm flows recede. The largest level response observed was approximately $9 \mathrm{~m}$ over 14 hours at Power Plant Pit on September 30, 2016.

Temperature was the parameter that was responsive to precipitation events at the lowest number of sites. Power Plant Pit exhibits a pronounced temperature response to nearly all precipitation events reflecting seasonal precipitation temperatures. 3-D Maze cave showed temperature changes in response to larger precipitation events that reflected seasonal temperatures. Brother Daves Cave exhibited increases in temperature after larger precipitation events, regardless of the season. 


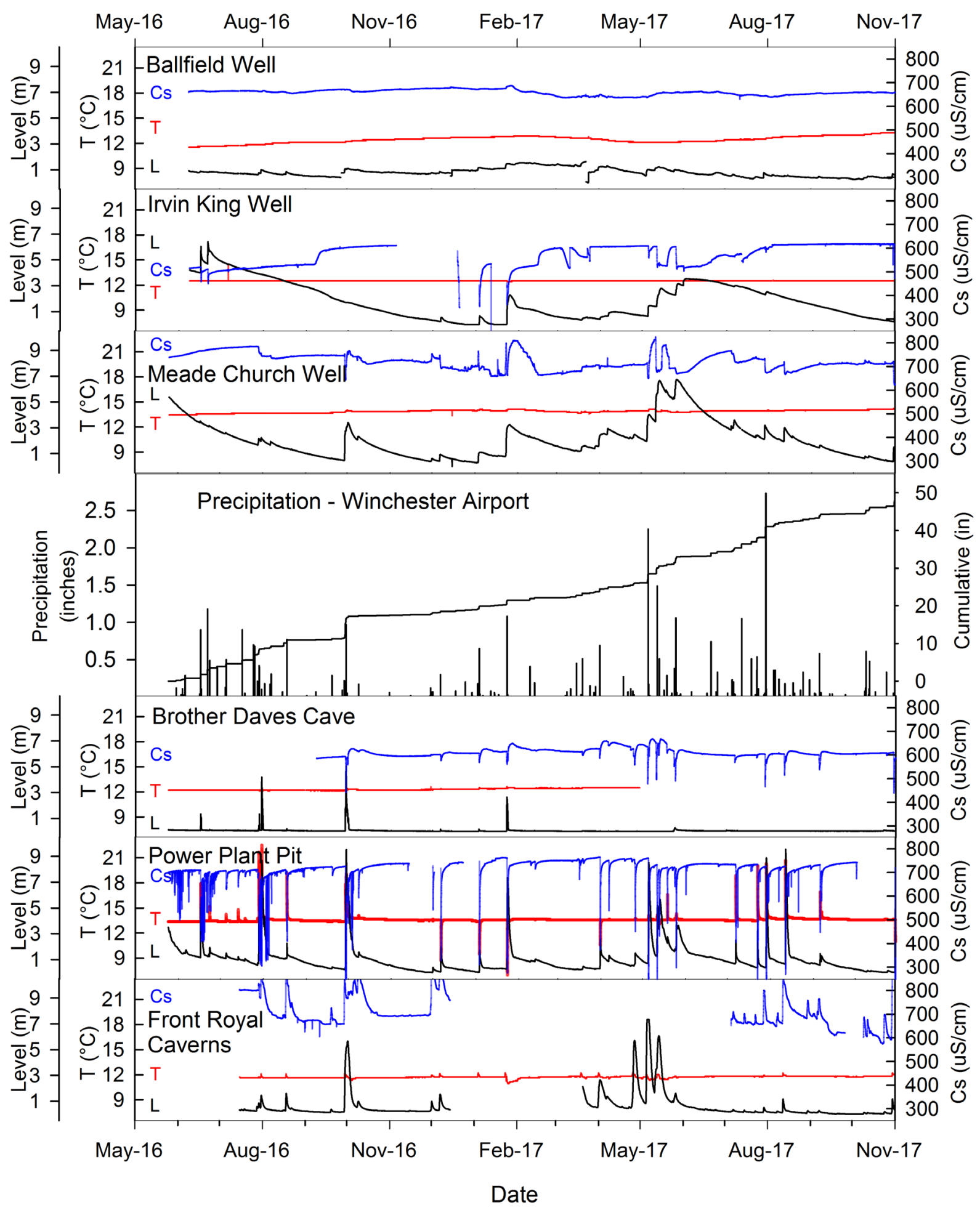

Figure 3. Time series data responses to precipitation events, Northern sites. 


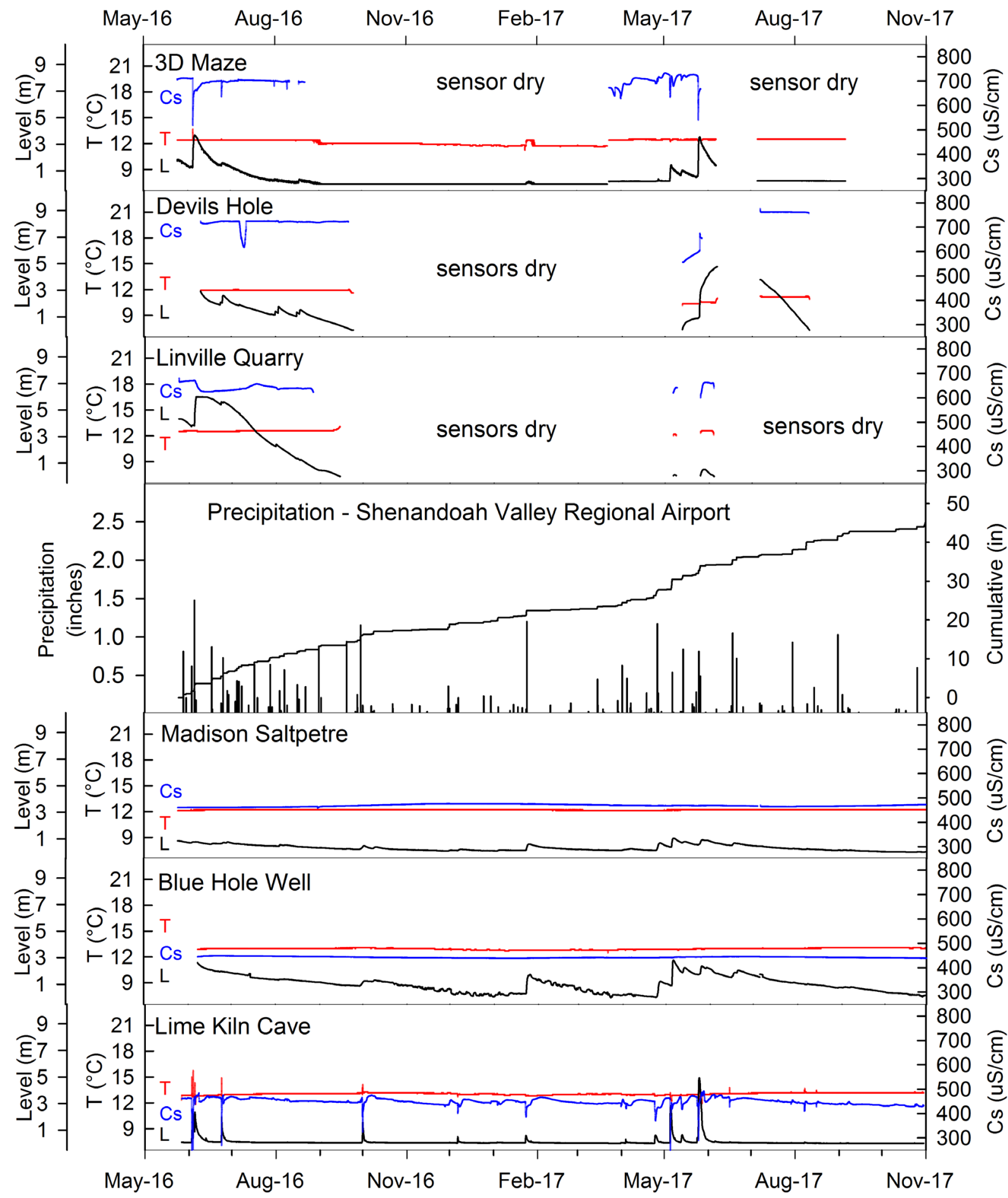

Date

Figure 4. Time series data responses to precipitation events, Southern sites. 
Front Royal Caverns exhibited temperature increases in response to precipitation events regardless of the season, but these increases were followed immediately by decreases in response to larger precipitation events during the cold season. Lime Kiln Cave exhibited a similar hybrid response to that of Front Royal Caverns. Meade Church Well showed a minimal response to a handful of the larger precipitation events, while Madison Saltpetre Cave, Blue Hole Well, Irvin King Well, and Ballfield Well showed no temperature response to any precipitation events. Incomplete datasets at Devils Hole and Linville Quarry caves showed no clear temperature response to precipitation events. The largest temperature increase response to a precipitation event was at Power Plant Pit, $\sim 9^{\circ} \mathrm{C}$ on July 31,2016 . The largest temperature decrease was also at Power Plant Pit, $\sim 7^{\circ} \mathrm{C}$ on January 23, 2017.

Specific conductance values responded to precipitation events at all but two sites, Madison Saltpetre Cave and Ballfield Well. Groundwater in Power Plant Pit significantly decreased in specific conductance in response to precipitation events, as did Irvin King Well and 3-D Maze Cave. Both Lime Kiln Cave and Brother Daves Cave reacted to most precipitation events with a negative spike followed by a small increase in specific conductance. Front Royal Caverns generally showed a spike in specific conductance after precipitation events, followed by decay to a different conductance value than prior to the event. Meade Church Well responded irregularly to precipitation events, generally decreasing after precipitation, but increasing after some of the larger, winter events. Ballfield Well exhibited only very small changes $(<30 \mu \mathrm{S} / \mathrm{cm})$. Data was insufficient to evaluate response at Devils Hole and Linville Quarry caves, though both show evidence of some response. The largest change at a site following a precipitation event was a decrease of $530 \mu \mathrm{S} / \mathrm{cm}$ at Power Plant Pit on September 30, 2016, while Front Royal Caverns (9/30/2016) and Meade Church Well (1/23/2017) both showed increases of $\sim 200 \mu \mathrm{S} / \mathrm{cm}$ after larger precipitation events.

Table 3 summarizes responsiveness characteristics of monitoring sites. Devils Hole and Linville Quarry had insufficient data to characterize overall response to precipitation, while Howard Tabb well was excluded due to apparent influence from well pumping and maintenance. All ten remaining sites showed water level changes in response to precipitation, seven exhibiting rapid rises, and three more moderate rises. Of the rapidly rising sites, three had levels return quickly to pre-event levels while another three showed more gradual water level falls after events. Seven sites showed changes in specific conductance, three negative, one positive, and three with compound responses. Six sites showed temperature changes: three seasonal, two positive, and one compound.

Geochemical analyses are displayed graphically on the Piper diagram in Figure 5. Raw water analyses are available from the author upon request. All samples plot as calcium-magnesium-bicarbonate type waters. Samples from Front Royal Caverns, Meade Church Well, Linville Quarry Cave, and Power Plant Pit exhibit slightly elevated chloride, sodium and sulfate levels. Total dissolved $(\mathrm{Ca}, \mathrm{Mg})^{2+}$ concentrations ranged from 1.8 to $4.1 \mathrm{mmol} / \mathrm{L}$, with dissolved organic carbon ranging from 4 to $9 \mathrm{mmol} / \mathrm{L}$. Figure 6 shows dissolved organic carbon (DIC as $\mathrm{HCO}_{3}^{-}$) plotted against $(\mathrm{Ca}, \mathrm{Mg})^{2+}$. Molar ratios were generally grouped by site, with several sites exhibiting variation across sampling events. The more alkaline waters were observed at Devils Hole Cave, 3-D Maze Cave, and the Howard Tabb Well. Samples from Blue Hole Well, Lime Kiln Cave, and Madison Saltpetre Cave exhibited consistently lower alkalinity values.

Chloride and nitrate levels are depicted in Figure 7. Chloride and nitrate concentrations in the sampled groundwater sites.. Chloride levels ranged from 2 to $63 \mathrm{mg} / \mathrm{L}$, grouped by site with some sites exhibiting seasonal variation. Higher chloride values were measured at Front Royal Caverns, Linville Quarry Cave,

\begin{tabular}{|c|c|c|c|}
\hline Site & Water Level & Temperature & $\begin{array}{c}\text { Specific } \\
\text { Conductance }\end{array}$ \\
\hline $3 \mathrm{DC}$ & fast & seasonal & Strong - \\
\hline $\mathrm{BDC}$ & $\begin{array}{c}\text { Fast rise, fast } \\
\text { decay }\end{array}$ & + , larger events & - then + \\
\hline $\mathrm{DHC}$ & fast & Insuff data & Insuff data \\
\hline FRC & $\begin{array}{c}\text { Fast rise, fast } \\
\text { decay }\end{array}$ & + then - & Strong + \\
\hline LKC & $\begin{array}{c}\text { Fast rise, fast } \\
\text { decay }\end{array}$ & seasonal & - then + \\
\hline LQC & fast & Insuff data & Insuff data \\
\hline MSE & $\begin{array}{c}\text { Rise then slow } \\
\text { decay }\end{array}$ & none & none \\
\hline PPP & $\begin{array}{c}\text { Fast rise, slow } \\
\text { decay }\end{array}$ & seasonal & Strong - \\
\hline $\mathrm{BFW}$ & $\begin{array}{c}\text { Rise then slow } \\
\text { decay }\end{array}$ & none & negligible \\
\hline BHW & $\begin{array}{c}\text { Rise then slow } \\
\text { decay }\end{array}$ & none & none \\
\hline IKW & $\begin{array}{c}\text { Fast rise, slow } \\
\text { decay }\end{array}$ & none & Strong - \\
\hline $\mathrm{MCW}$ & $\begin{array}{c}\text { Fast rise, slow } \\
\text { decay }\end{array}$ & Weak + & variable \\
\hline
\end{tabular}

Table 3. Site groundwater responses to precipitation. Site abbreviations listed in Table 1. 
Meade Church Well, and Power Plant Pit. Lower chloride values were observed at Madison Saltpetre (East Lake), Brother Daves, and Lime Kiln caves. Nitrate (N) levels ranged from 1 to $12 \mathrm{mg} / \mathrm{L}$, grouped by site with some sites exhibiting seasonal variation. Higher nitrate values were Irvin King and Howard Tabb wells in spring and summer, respectively. Nitrate values were consistently low $(<2 \mathrm{mg} / \mathrm{L})$ at Madison Saltpetre (East Lake), Lime Kiln, and Front Royal Caverns.

Variability in the water isotope compositions of the phreatic ground water samples collected in this study is small. The average $\delta^{2} \mathrm{H}$ and $\delta^{18} \mathrm{O}$ compositions of all the sites overlap with the winter season (Nov-April) amountweighted precipitation measured at Grottoes, Virginia (Figure 8. Stable isotope composition of precipitation collected at Grottoes, Virginia in 2016 compared to the groundwater samples collected in this study.,) and the mean $\delta^{18} \mathrm{O}$ value of $-7.9+/-0.3$ per mil coincides with the mean value of drip waters collected in Grand Caverns (see Benton and Doctor, 2018, this volume.)
Precipitation samples fall on a local meteoric water line (LMWL) that closely parallels the global meteoric water line (GMWL). The average value of mean annual amount-weighted precipitation, and the value of amountweighted precipitation for the late winter and early spring months of January, February, March, and April (JFMA) are plotted on Figure 8. Stable isotope composition of precipitation collected at Grottoes, Virginia in 2016 compared to the groundwater samples collected in this study. for reference.

Site occupancy results are displayed in Figure 9. Site occupancy over the duration of this study of known Antrolana lira sites by taxon, habitat access (cave or well), and method of sampling ( $\mathrm{t}$ - trapping, $\mathrm{v}$ - visual observation or collection).. Results expressed as percent of events when taxon was detected \pm standard error. Source data is displayed in the table below the histogram as number of sampling events during which taxon was observed. Overall, $A$. lira was more likely to be detected in a cave using trapping and visual surveys (50\%) than in

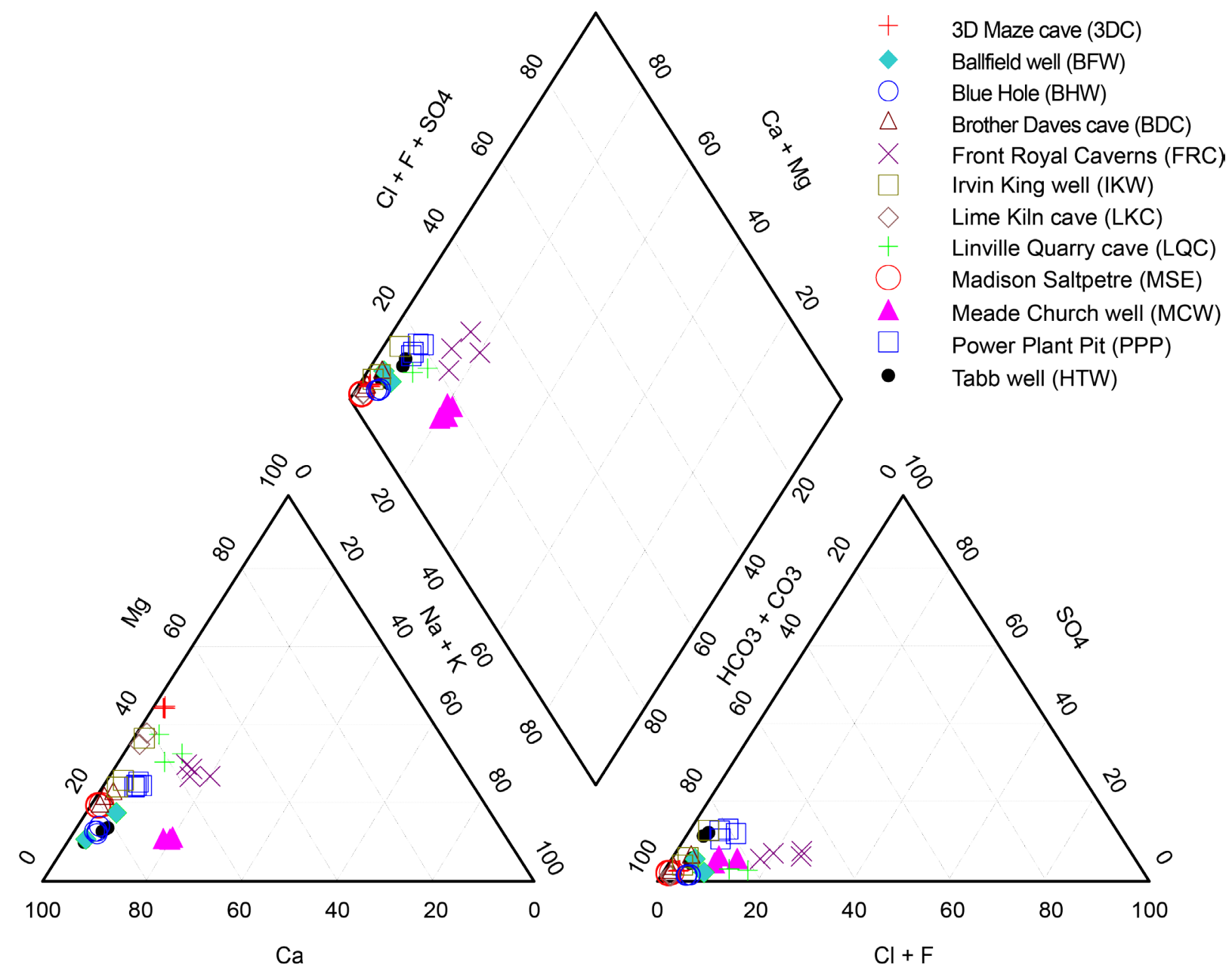

Figure 5. Piper diagram illustrating the distribution of the groundwater samples according to major ion chemistry. 


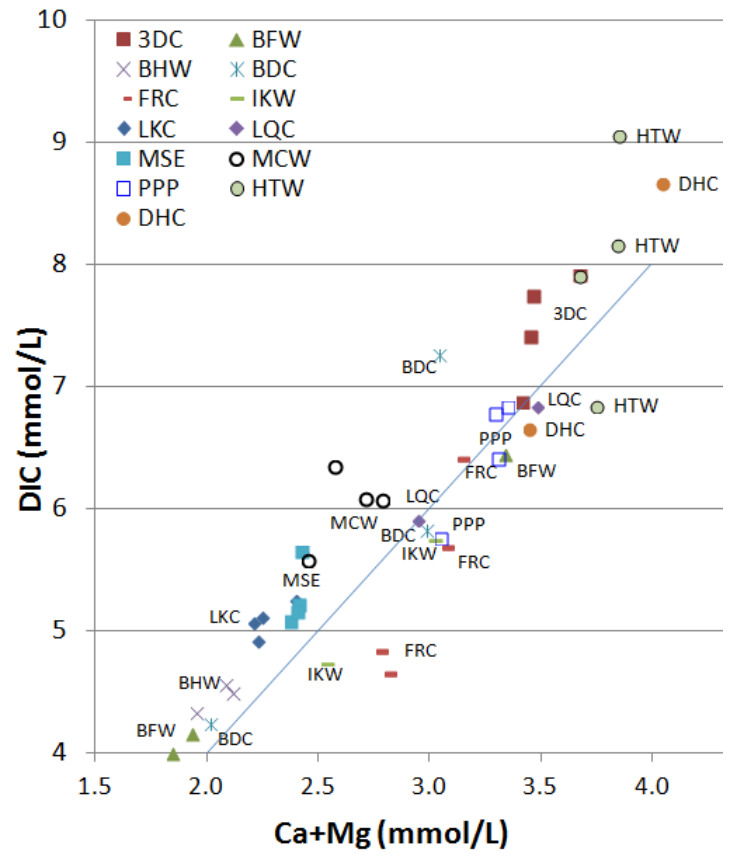

Figure 6. Concentrations of dissolved carbonate minerals for each sample.

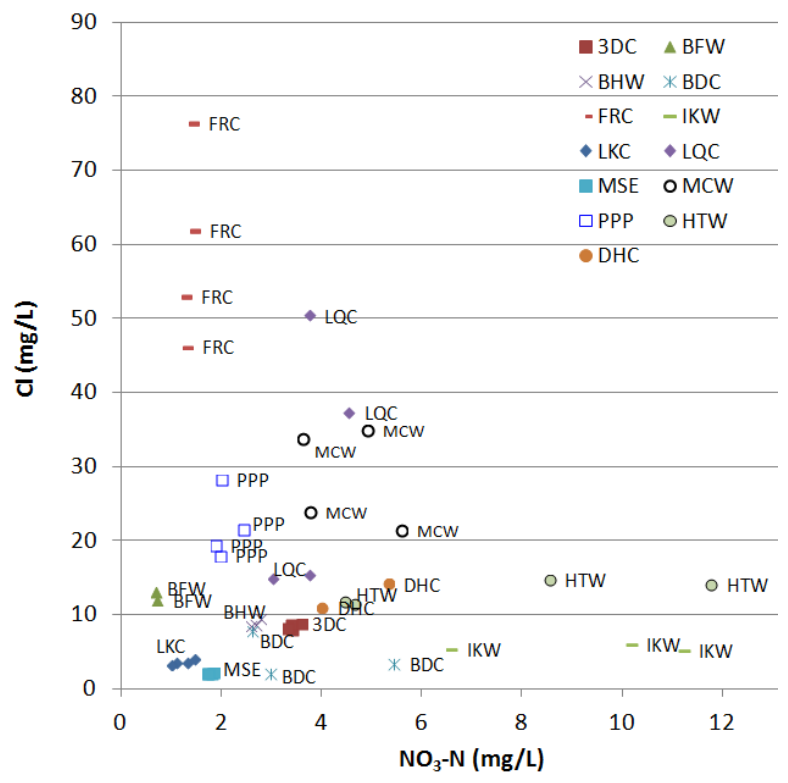

Figure 7. Chloride and nitrate concentrations in the sampled groundwater sites.

wells using baited traps (14\%). Baited traps were more effective capturing A. lira in caves (32\%) than in wells (14\%). Both large and small specimens of the amphipod genus Stygobromus exhibited similar site occupancy patterns. Asellid isopods of the genus Caecidotea were detected visually in many caves near the intersection of vadose and phreatic waters, but were only trapped successfully $5 \%$ of the time. Groundwater planaria were collected in a single trapping event.

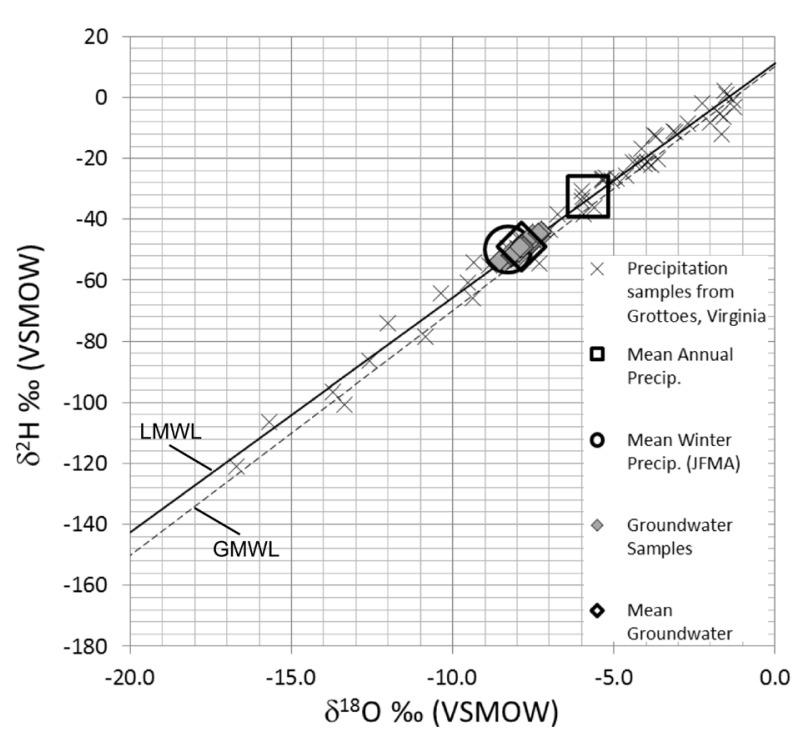

Figure 8. Stable isotope composition of precipitation collected at Grottoes, Virginia in 2016 compared to the groundwater samples collected in this study.

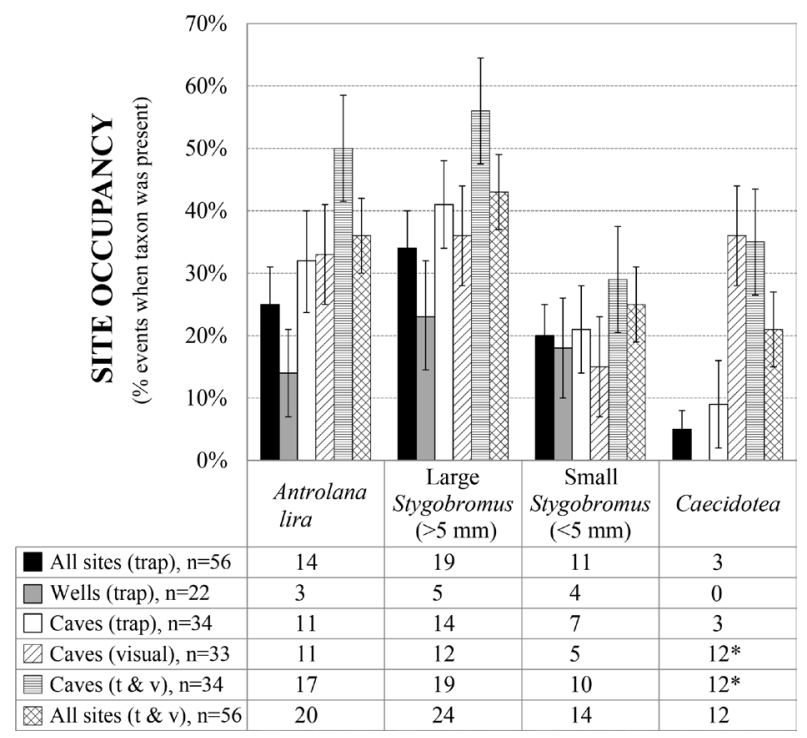

Figure 9. Site occupancy over the duration of this study of known Antrolana lira sites by taxon, habitat access (cave or well), and method of sampling ( $t$ - trapping, $v$ - visual observation or collection).

Table 4. Site occupancy by site and species $\left(0^{*}\right.$ indicates previously known from site but not present over the duration of this study; **includes vadose zone observations.) Stygobromus species are 1-gracilipes, 2biggersi, 3-stegerorum, 4-baroodyi, ?-undetermined; $\mathrm{C}$ are Caecidotea species isopods. Site abbreviations listed in Table 1. presents a breakdown of stygobitic crustaceans observed by site and species. Stygobitic crustaceans were detected at least once from all sampled 


\begin{tabular}{|l|c|c|c|c|c|c|c|c|}
\hline \multirow{2}{*}{ Site } & \multirow{2}{*}{ N } & \multirow{2}{*}{$\begin{array}{c}\text { A. } \\
\text { lira }\end{array}$} & & \multicolumn{7}{|c|}{ Stygobromus species } & \multirow{2}{*}{ C } \\
\cline { 1 - 6 } Caves: & & & & & & & & \\
\hline 3DC & 5 & $0 *$ & 2 & NA & NA & NA & 1 & 0 \\
\hline BDC & 3 & $0 *$ & 3 & 0 & NA & NA & NA & 3 \\
\hline DHC & 3 & 3 & 3 & NA & NA & NA & 1 & 1 \\
\hline FRC & 5 & 2 & 3 & $?$ & NA & NA & 1 & 0 \\
\hline LKC & 5 & $0 *$ & NA & NA & NA & 1 & & 4 \\
\hline LQC & 5 & 4 & 3 & NA & NA & NA & 0 & 0 \\
\hline MSE & 4 & 4 & 1 & NA & 4 & NA & & 0 \\
\hline PPP & 4 & 4 & 3 & 1 & NA & NA & & 4 \\
\hline Wells: & & & & & & & & \\
\hline BFW & 3 & 2 & 1 & 0 & NA & NA & & 0 \\
\hline BHW & 5 & $0 *$ & 1 & NA & $0 *$ & NA & & 0 \\
\hline HTW & 5 & $0 *$ & 2 & 0 & NA & NA & & 0 \\
\hline IKW & 4 & 1 & 0 & 1 & NA & NA & & 0 \\
\hline MCW & 5 & $0 *$ & 1 & 3 & NA & NA & & 0 \\
\hline
\end{tabular}

the study. By contrast, Power Plant Pit, 3-D Maze, and Lime Kiln caves showed seasonal temperature responses and negative changes in specific conductance indicating direct and rapid connection to surface drainage. The remaining sites exhibited more complex responses, suggesting that multiple flow paths delivered a combination of surface water and displaced groundwater to these monitoring locations. The displacement component in particular resulted in such seemingly paradoxical responses as the increase in temperatures at Brother Daves Cave and Front Royal Caverns following precipitation events, even in winter. The temperature increases were accompanied by decreases then increases in specific conductance at Brother Daves Cave as water from different flow paths arrived at the monitoring site.

Baseline temperatures across the study area show no obvious geographic trends, suggesting that variations are likely due to differences in depth and rate of groundwater circulation across sites.

Table 4. Site occupancy by site and species $10^{*}$ indicates previously known from site but not present over the duration of this study; **includes vadose zone observations.) Stygobromus species are 1-gracilipes, 2-biggersi, 3-stegerorum, 4-baroodyi, ?undetermined; C are Caecidotea species isopods. Site abbreviations listed in Table 1.

sites. Madison cave isopods were observed at seven of the sites, one or more amphipod species were observed at all thirteen sites, and Caecidotea species isopods were observed at four of eight cave sites. Caecidotea species are benthic and difficult to trap in wells, so the lack of capture should be interpreted as a failure to detect rather than as absence from the habitat. Madison Cave isopods were detected at all sampling events at Madison Saltpetre Cave, Power Plant Pit, and Devils Hole. Highest species diversity was observed at Devils Hole (4) and Power Plant Pit (4.) No more than two crustacean species were observed from any of the wells during this study, though a total of three species are known from Meade Church Well (Orndorff and Hobson, 2007).

\section{Discussion}

Time series data for level, temperature, and specific conductance portray a high degree of variability among sites in terms of the immediate influence of surface water on phreatic habitat. Madison Saltpetre Cave, Blue Hole Well, and Ballfield well exhibit relatively slow rises in water levels after precipitation events, with zero to negligible changes in temperature or specific conductance. These sites are highly isolated from immediate surface water influences and were geochemically and thermally stable over the course of

The variability in baseline temperature and conductivity values, water chemistry, and response to precipitation events, even over short distances, supports the notion of a highly compartmentalized phreatic zone. For example, the water filled fissure passages in Brother Daves Cave and Power Plant Pit, separated by $\sim 100 \mathrm{~m}$ horizontally, have respective median temperature values of 12.2 and $13.6^{\circ} \mathrm{C}$ and conductivity values of 607 and $726 \mu \mathrm{S} / \mathrm{cm}$. Water chemistry is distinctly different between the sites as well (Figure 5, Figure 6, Figure 7. Chloride and nitrate concentrations in the sampled groundwater sites..) A physical survey performed in 2002 showed the water level in Brother Daves Cave to be approximately four meters higher than that in Power Plant Pit (Orndorff, 2016a, 2016b). Such thermal, chemical, and physical gradients could not be supported over such a short distance within the phreatic zone, requiring that any connection between these two sampling locations is highly circuitous and intermittent. The difference in patterns of response to precipitation between these two sites is further evidence of their isolation under most conditions. An alternative hypothesis to explain these observations is that the sump lake in Brother Daves Cave is the result of rising phreatic waters trapped in a vadose passage following larger recharge events, stranding stygobitic fauna from the phreatic zone and mixing with local epikarstic recharge and direct recharge from smaller precipitation events. However, temperature increases in the Brother Daves Cave sump in response to most precipitation events, regardless of season, support a more continuous connection to deeper, phreatic water, favoring the hypothesis of compartmentalized phreatic zones. 
As shown in Figure 5, waters in the study area are typical of karst groundwaters around the world. Major carbonate mineral ions at all sites plot near the $(\mathrm{Ca}, \mathrm{Mg})^{2+}$ versus $\mathrm{HCO}_{3}^{-}$line.

Chloride and nitrate levels reflect nearby land-use activities affecting the groundwater at the sampling sites (Figure 7. Chloride and nitrate concentrations in the sampled groundwater sites.). Those sites that show higher chloride levels ( $>15 \mathrm{mg} / \mathrm{L})$ are likely affected by salt in road runoff or other sources of chloride from land use activities. These sites include Front Royal Caverns, Meade Church well, Power Plant Pit, and Linville Quarry. Front Royal Caverns lies directly beneath and adjacent to US Route 340 just south of Front Royal. Meade Church well is in the hamlet of White Post immediately adjacent to US Route 340 in Clarke County. Power Plant Pit lies along a swale that receives discharge from several industrial stormwater management facilities. Linville Quarry Cave has no obvious connection to a source of elevated chloride.

The nitrate data help to identify sites with some possible agricultural contamination. Only two sites, Irvin King well and Tabb well, exceeded the drinking water standard of $10 \mathrm{mg} / \mathrm{L}$ nitrate as N. Irvin King well lies immediately adjacent to a several hundred acre cornfield, and Tabb well is $\sim 100$ meters down gradient along a swale from an active barnyard. Background nitrate concentrations of most groundwater in the carbonates of the Appalachian Great Valley aquifer vary between 2.0 to $5.0 \mathrm{mg} / \mathrm{L}$ nitrate as N (Lindsey et al., 2009). Sites that fall consistently below that level are likely to be unaffected by local surface agricultural activities. Such sites include Lime Kiln Cave, Madison Saltpetre Cave (East Lake), Front Royal Caverns, and Ballfield well.

The consistent isotope composition results across sites and sampling events indicate that cool-season precipitation supplies the majority of recharge to the greater aquifer at large, supporting previous conclusions about the strong seasonality of epikarstic recharge from work done at James Cave (Eagle et al., 2015), and in Grand Caverns (Benton and Doctor, 2018, this volume). This suggests that the majority of the water in the aquifer in long-term storage originated as precipitation stored in and subsequently discharged from the epikarst. The influence on overall recharge by surface water bypassing the epikarst and directly entering the phreatic zone, as documented at several sites in the time series data during summer months, appears relatively minor. However, such bypass flow can introduce disproportionate amounts of contamination into the aquifer locally as a function of land use practices.
No relationships of site occupancy or stygobitic crustacean diversity to time series data or geochemistry were apparent in this study. Two of the three sites with 100\% site occupancy by the Madison Cave isopod were Madison Saltpetre Cave and Power Plant Pit, which comprise the two end members of study sites in terms of degree of variability and surface water influence. However, caution should be used in interpreting this result. Abundance was not considered as part of this study, and greater numbers of Madison Cave isopods are regularly present at Madison Saltpetre Cave than at Power Plant Pit. Furthermore, in prior studies isopods exhibited much lower site occupancy at Power Plant Pit than at Madison Saltpetre Cave (Orndorff, 2014a, 2014b). While Madison Saltpetre Cave should still be considered the highest quality and best protected site for the Madison Cave isopod, this study clearly shows that it and other associated stygobionts tolerate a wide range of geochemical and hydrological conditions, and continue to persist at sites with ongoing negative impacts from land use practices.

This study demonstrates the value of combining high resolution time series data with geochemical analyses and biological monitoring to characterize karst groundwater systems. Phreatic karst aquifers developed within the carbonate bedrock of the Great Valley exhibit complexity and heterogeneity both in terms of baseline chemical and physical parameters and the nature and degree of response to precipitation events. Increased collection and analysis of such data would facilitate better decisions in regards to both aquifer management and habitat conservation.

\section{Acknowledgements}

This research was supported by the United States Fish and Wildlife Service Contract F15PX00336 with the Virginia DCR Natural Heritage Program, and a grant from Dominion Energy. Bill Balfour, Jon Lillestolen, and Jeff Jahn made significant contributions to the cave survey and installation of monitoring equipment at Power Plant Pit and Brother Daves caves. Lauren Brandes (USGS) provided oxygen and hydrogen stable isotope analyses of water. The authors wish to thank all the property owners involved in the study for graciously allowing access to their caves and wells. Any use of trade, firm, or product names is for descriptive purposes only and does not imply endorsement by the U.S. Government.

\section{References}

Benton JR, Doctor DH. 2018. Investigating vadose zone hydrology in a karst terrain through hydrograph and chemical time series of 
cave drips at Grand Caverns, Virginia. (this volume)

Bowman TE. 1964. Antrolana lira, a new genus and species of troglobitic cirolanid isopod from Madison Cave, Virginia. International Journal of Speleology 1:229-236.

Collins TL, Holsinger JR. 1981. Population ecology of the troglobitic isopod crustacean Antrolana lira Bowman (Cirolanidae). Proceedings of the 8th International Congress of Speleology 1:129-132.

Holsinger JR, Culver DC, Hubbard DA, Orndorff WD, Hobson CS. 2013. The Invertebrate Cave Fauna of Virginia. Banisteria, No. 42, p. 9-56.

Eagle S, Orndorff W, Schwartz B, Doctor DH, Gerst J, Schreiber M. 2015. Analysis of hydrologic and geochemical time-series data at James Cave, Virginia: Implications for epikarst influence on recharge in Appalachian karst aquifers, in Feinberg J, Gao Y, Alexander, Jr. EC, eds., Caves and Karst Across Time: Geological Society of America Special Papers, 516, p. SPE516-15, first published on August 6, 2015, https://doi. org/10.1130/2015.2516(15).

Fong DW. 2007. Mark-recapture populations size estimates of the Madison Cave isopod, Antrolana lira [abs.]: Journal of Cave and Karst Studies, v. 69 , no. 3 , p. 360.

Fong D. 1996. Madison Cave Isopod (Antrolana lira) Recovery Plan. U.S. Fish and Wildlife Service, Hadley, Massachusetts, U.S.A.

Holsinger JR, Hubbard, Jr. DA, Bowman TE. 1994. Biogeographic and ecological implications of newly discovered populations of the stygobiont isopod crustacean Antrolana lira Bowman (Cirolanidae). Journal of Natural History 28:1047-1058.

Hutchins B, Fong DW, Carlini DB. 2010. Genetic Population Structure of the Madison Cave Isopod, Antrolana lira (Cymothoida: Cirolanidae) in the Shenandoah Valley of the Eastern United States. Journal of Crustacean Biology, v. 30, no. 2, p. 312-322.

Hutchins B, Orndorff W. 2009. Effectiveness and adequacy of well sampling using baited traps for monitoring the distribution and abundance of an aquatic subterranean isopod. Journal of Cave and Karst Studies, v. 71, no. 3, p. 193-203.

Lindsey BD, Berndt MP, Katz BG, Ardis AF, Skach KA. 2009. Factors affecting water quality in selected carbonate aquifers in the United States, 1993-2005: U.S. Geological Survey Scientific Investigations Report 2008-5240, 117 p. https:// pubs.usgs.gov/sir/2008/5240/.
Orndorff WD. 2008. Inventory for Antrolana lira and associated stygobitic invertebrates from the Shenandoah and Potomac Valleys, Berkeley and Jefferson Counties, West Virginia. Final report to the West Virginia Division of Natural Resources Wildlife Resources Section, Elkins, WV. 7 p.

Orndorff WD. 2012. Mark-recapture population estimates for the Madison Cave isopod (Antrolana lira) at several sites in the Shenandoah Valley, Virginia. Natural Heritage Technical Report 12-06. Virginia Department of Conservation and Recreation, Division of Natural Heritage, Richmond, Virginia. 7 p plus 4 appendices.

Orndorff WD. 2014a. Monitoring for potential impacts to Madison Cave Isopod habitat: Annual Report Dominion Warren Power Plant Project (May, 2011 through July, 2012). Natural Heritage Technical Report 14-03. Virginia Department of Conservation and Recreation, Division of Natural Heritage, Richmond, Virginia. 21 p plus 3 appendices.

Orndorff WD. 2014b. Monitoring for potential impacts to Madison Cave Isopod habitat: annual report Dominion Warren Power Plant Project (Year 2: April 16, 2012-April 15, 2013). Natural Heritage Technical Report 14-06. Virginia Department of Conservation and Recreation, Division of Natural Heritage, Richmond, Virginia. 27 p plus 1 appendix.

Orndorff WD. 2016a. Monitoring for potential impacts to Madison Cave Isopod habitat: annual report Dominion Warren Power Plant Project (Year 3: April 16, 2013-April 15, 2014). Natural Heritage Technical Report 2014-07. Virginia Department of Conservation and Recreation, Division of Natural Heritage, Richmond, Virginia. 28 p plus 2 appendices.

Orndorff WD. 2016b. Monitoring for potential impacts to Madison Cave Isopod habitat: annual report Dominion Warren Power Plant Project (Year 4: April 16, 2014-April 15, 2015). Natural Heritage Technical Report 2016-19. Virginia Department of Conservation and Recreation, Division of Natural Heritage, Richmond, Virginia. 29 p plus 1 appendix.

Orndorff WD, Hobson CS. 2010. Reconnaissance Survey of Phreatic Groundwater Habitat beneath the South Fork Shenandoah (Page) Valley for the Madison Cave Isopod (Antrolana lira) and other Stygobionts, 2008-2010. Natural Heritage Technical Report 10-20. Virginia Department of Conservation and Recreation, Division of Natural Heritage, Richmond, Virginia. 9 p. 
Orndorff WD, Hobson CS. 2007. Status Survey for the Madison Cave Isopod (Antrolana lira) in Virginia, 2005-2007. Natural Heritage Technical Report 07-11. Virginia Department of Conservation and Recreation, Division of Natural Heritage, Richmond, Virginia. $17 \mathrm{p}$.

Printz CM. 1999. Characterization of the habitat of the Madison Cave isopod (Antrolana lira) at Massanutten Caverns, Linville Quarry Cave \#3, and 3-D Maze Cave, Rockingham County, VA. Unpublished report to the US Fish and Wildlife Service, James Madison University, Harrisonburg, VA. 23 p.

Révész KM, Doctor DH. 2014. Automated determination of the stable carbon isotopic composition $(\delta 13 \mathrm{C})$ of total dissolved inorganic carbon (DIC) and total nonpurgeable dissolved organic carbon (DOC) in aqueous samples: RSIL lab codes 1851 and 1852: U.S. Geological Survey Techniques and Methods, book 10, chap. C20, 38 p. https://doi.org/10.3133/tm10C20.

Weary DJ, Doctor DH. 2014. Karst in the United States: A digital map compilation and database: U.S. Geological Survey Open-File Report 2014-1156, 23 p. https://doi.org/10.3133/ofr20141156. 
